\title{
Standard Issuance of Circular Letters in The Implementation Of Judicial Power
}

\author{
Rahadi Wasi Bintoro ${ }^{1, *}$, Abdul Shomad ${ }^{2}$, Trisadini Prasastinah Usanti ${ }^{2}$ \\ ${ }^{1}$ Department of Procedural Law, Faculty of Law Universitas Jenderal Soedirman, Purwokerto, \\ Indonesia \\ ${ }^{2}$ Department of Private Law, Faculty of Law Universitas Airlangga, Surabaya, Indonesia \\ ${ }^{3}$ Department of Private Law, Faculty of Law Universitas Airlangga, Surabaya, Indonesia
}

\begin{abstract}
Circular issued by state institutions in the framework of the freies ermessen principle. Circular in administrative law is known as policy regulation/ belleidsregel. The Supreme Court as a state institution also has the authority to issue circular letters. This paper focused on the standard circular issued by the Supreme Court. This paper was legal research that was carried out with the statute approach and conceptual approach. Based on the analysis, circulars issued by the supreme court contained restrictions, namely that they should not influence the judge in examining the case.
\end{abstract}

Keywords: state institution, freies ermessen principles, circular letter, judge independence

\section{Introduction}

In the concept of the rule of law ${ }^{[1]}$, all actions taken must rely on the law. One of the legal products is legislation. In order to regulate the establishment of a law and regulation, Law Number 12 Year 2011 concerning the Establishment of Legislation is established. In fact, agency or official of the State Administrative often take a variety of specific policy measures, such as creating a policy regulation (beleidsregel). This product is inseparable from the connection of the use of freies ermessen principles, that is the actions of the government (state administration) which requires freedom to be able to act on its own initiative, especially in resolving issues that require immediately because the regulations for the resolution of the problem do not yet exist.

Policy regulations that are usually outlined in the form of circulars ${ }^{[2]}$ are also needed in carrying out the duties and functions of the Supreme Court as part of the government. Keep in mind, that Government is a state tool that can be interpreted broadly and in a narrow sense. Government in a broad sense includes all state apparatus, which occurs from the branches of the executive, legislative and judicial powers or other state apparatus that act for and on behalf of the state, while the Government can also be interpreted in the narrow sense of the implementation of office executive or more importantly, the government as the organizer of

* Corresponding author: rahadiwasibintoro@gmail.com 
state administration. In the context of government in this broad sense, the concept of good governance $^{[3]}$ is also attached to the supreme court. The Supreme Court is one of the perpetrators of judicial power ${ }^{[4]}$ in Indonesia, which includes the principle of independence in carrying out the duties and functions of the power of the judiciary.

\section{Objective of the Study}

Based on this explanation, this paper focuses on the standard circular letter as a belleids regel in carrying out the duties and functions of the judicial authority in the Supreme Court.

\section{Methodology}

This paper is a legal research that uses a legislative approach, and a conceptual approach. The sources of law in this paper come from laws and regulations, especially those relating to the judicial authority, as well as the literature related to the legal issues raised. Analysis is carried out qualitatively.

\section{Discussion}

Circular or belleidsregel in doctrine is considered as quasi-legislation. quasi-legislation plays an important role in government bureaucracies everywhere in the world, including in Indonesia. Quasi-legislation is a form of public legal instrument used to carry out tasks previously regulated in general in a law. Therefore, this arrangement is still general/ abstract, so a circular is needed for the implementation phase.

Circular in administrative law is known as policy regulation, the discussion of its is inseparable from the theory of legislation. The terminology of the legislation comes from the term wettelijke regels or wettelijke regeling. The term wet (law) in Dutch law has two meanings, ${ }^{[5]}$ First, wet in fomele zin (law in a formal sense) is any government decision which includes laws based on the form and manner of its formation; Second, wet in materiele zin (legislation in a material sense), namely the decision of the government / authorities which is seen based on the content or substance directly binding on the population or a particular area, for example: government regulations, presidential regulations, ministerial regulations, regional regulations and so on.

Bagir Manan ${ }^{[6]}$ provides an understanding of laws and regulations as a written legal rule made by an authorized official or an authorized position environment that contains abstract and general rules of conduct. Whereas according to I Gde Pantja Astawa ${ }^{[7]}$ which is called the state regulation (staatsregelings) is a broad decision (besluiten) qualified in 3 (three) groups namely: First, Wettelij regeling (laws and regulations), such as the Constitution, laws, government regulations in lieu of laws, government regulations, presidential regulations, ministerial regulations, regional regulations, etc.; Second, Beleidsregels (policy regulations), such as instructions, circulars, announcements and others; and Third, Beschikking (determination), such as a decree.

Policy regulations (beleidsregel, spiegelsrecht, pseudowetgeving or policy regulation) are rules made by the government as state administrations whose implementation of its authority is not based on the provisions of the of legislation but based on the principle of freedom on action (beleidsvrijheid or vrijheid beoordelings) or Freies Ermessen. Bagir Manan ${ }^{[8]}$ gave several notes regarding policy regulations as follows: First, Policy regulations are not one form or type of legislation; Second, The implementation of the policy is not contained in the form of legislation, because policy makers do not have legislative authority (both attribution and delegation); Third, As a "rule" that is not a legislation product, policy regulations are not 
directly legally binding but contain legal relevance; Fourth, Policy regulations are basically addressed to the state administration agency or official; Fifth, The making of policy regulations is needed in order to ensure compliance with the principles of law; Sixth, the form of policy regulation is a declaration formulated in general and written. Two main forms of policy regulation, First: policy regulations that are made and applicable to the policy makers themselves. Second: policy regulations that are made and apply to administrative bodies or officials who are subordinate to policy makers; Seventh, Policy regulations are not laws and regulations, so the principles of law and concept of judicial review cannot be applied to policy regulations; Eight, The making of policy regulations is based on Freies Ermessen Principles. Testing of policy regulations is more directed to the doelmatigheid and therefore the test instrument is general principles of good governance $\left.{ }^{[9]}[10]\right]$; Ninth, Policy regulations are based on legal principles, if not, then it is arbitrary.

The Supreme Court in carrying out the duties and functions of the judicial authority, also has the authority to issue circular letters. However, in conducting quasi- legislation in the field of judicial power, it is necessary to pay attention to the principle of independence which is the basic principle of judicial power. The principle of independence of the judicial power is regulated in Article 24 paragraph (1) of the 1945 Constitution that the judicial power is an independent power to conduct justice in order to enforce law and justice. This independence is reaffirmed in Article 1 number 1 of Act Number 48 Year 2009, that "Judicial Power is the power of an independent state to hold a judiciary to enforce law and justice based on Pancasila and the 1945 Constitution of the Republic of Indonesia, for the implementation of the State Republic of Indonesia Law ", then Article 3 paragraph (1) of Law Number 48 of 2009 stipulates that "In carrying out its duties and functions, judges and constitutional judges must maintain judicial independence". in its explanation what is meant by "judicial independence" is free from outside interference and free from all forms of pressure, both physical and psychological.

The independence of judicial power then realized in administrative independence, financial independence and organizational independence. This is stated in Article 21 paragraph (1) of Law Number 48 of 2009 concerning judicial power that has granted authority to the Supreme Court to regulate its own organization, administration and even financial. However, the implementation of independence principles must pay attention to the provisions of Article 32 paragraph (5) of Law Number 3 Year 2009 concerning the Second Amendment to Law Number 14 Year 1985 concerning the Supreme Court, that in carrying out its duties and functions, the Supreme Court must not reduce the judge's freedom in examine and decide cases.

Based on this, then in a judge, he has two positions, First a judge as a government apparatus (state official) and the Second, judges as judges (case examiners). In the judge as judges (case examiners), he must explore, follow, and understand the legal values and sense of justice that lives in society, while in the judge as a state / government apparatus, he is state officials under the Supreme Court, in this condition the judge must obey the rules in place are sheltered. Provisions in Article 32 paragraph (5) of Law Number 3 Year 2009, if connected with the authority of the Supreme Court to issue a circular letter, there are restrictions on the establishment of a circular letter in the Supreme Court, that the Supreme Court circular letter may not affect the judge in making a decision for the case he is examining.

\section{Conclusion}

The Supreme Court as the perpetrator of the judicial power has the authority to issue a circular letter. The establishment of a circular letter must pay attention to the principle of 
independence of the power of the judiciary, therefore the circular issued must not limit the independence of the judge to impose a decision on the case he examined.

\section{References}

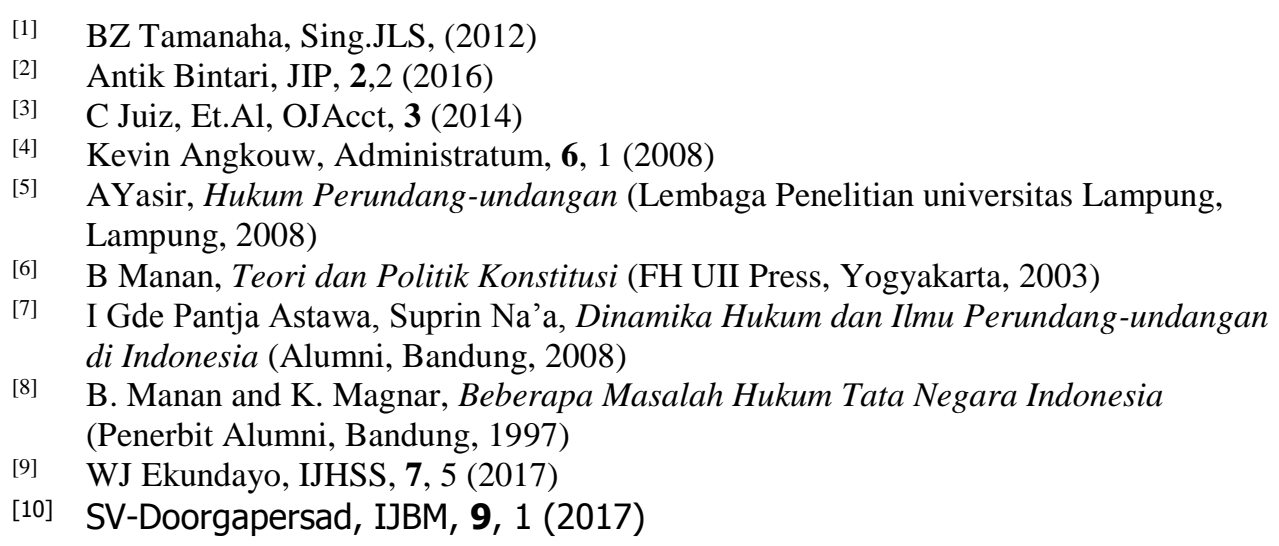

